\title{
The symbolization of sites of memory in Naquela Noite, a short story by the guinean writer Odete Semedo
}

\author{
A simbolização dos lugares de memória no conto "Naquela Noite" da escritora \\ guineense Odete Semedo
}

Wellington Marçal de Carvalho²

Data de Submissão: 23 mai. 2020.

Data de Aprovação: 25 jun. 2020.

Data de Publicação: 30 jun. 2020.

\begin{abstract}
The present work approaches the way Odete Semedo, in her literary text and specifically in the short story Naquela Noite, uses strategies which can be considered as a possible symbolization of "sites of memory". Such strategies reinforce resistance mechanisms and indicate ways of survival to go through difficult periods in the troubled space of Guinea-Bissau. The discussion that is now underway intends to endorse part of the thought of Amilcar Cabral, the most expressive revolutionary leader on the Guinean ground, in which the greater meaning of his people's struggle for independence is clarified. Cabral's lucid perception seems to be the same that can be seen in the work carried out by Semedo when he enacts, in his literary project, possibilities for the Guinean people to assume, even with great difficulties, the direction of their destiny. The strategies assumed by the writer configure a literary project of a politicized nature. This work, fueled by these reflections, can verticalize the discussion by focusing on the symbolization of "sites of memory" in Semedo's text, emphasizing, in the enunciation of it, its performativity as a beacon of resistance and an input for survival to overcome the harshness of current times of Guinea-Bissau. In Naquela Noite, Semedo's dexterity is proven by her skill of handling the concomitance of divergent times and spaces, as well as the remains of traditions threatened with extinction due to the acceleration of history.
\end{abstract}

Keywords: Decolonization. Memory. Guinean Literature criticism and interpretation.

\begin{abstract}
RESUMO: O presente trabalho abordará o modo como Odete Semedo em seu texto literário, especificamente no conto "Naquela noite", vale-se de estratégias que podem ser consideradas uma possível simbolização dos "lugares de memória". Tais estratégias reforçam mecanismos de resistência e indicam formas de sobrevivência para atravessar períodos difíceis do conturbado espaço da Guiné-Bissau. A discussão que ora se inicia pretende referendar trecho do pensamento de Amílcar Cabral, o mais expressivo líder revolucionário do chão guineense, no qual se esclarece o sentido maior da luta de seu povo pela independência. A lúcida percepção de Cabral parece ser a mesma que se depreende do trabalho realizado por Semedo quando encena, em seu projeto literário, possibilidades de o povo guineense assumir, ainda que seja com grandes dificuldades, a condução do seu destino. As estratégias assumidas pela escritora configuram, podese afirmar, um projeto literário de feição politizada. Este trabalho, alimentado por essas reflexões, pode verticalizar a discussão focalizando a simbolização dos "lugares de memória" em texto de Semedo, ressaltando, na enunciação do mesmo, sua performatividade enquanto balizador de resistência e insumo de sobrevivência para atravessar a dureza dos tempos atuais da Guiné-Bissau. Em "Naquela noite" ficou comprovada a destreza de Semedo em manejar a concomitância de tempos e espaços divergentes, assim como os restos de tradições ameaçadas de extinção pela aceleração da história.
\end{abstract}

\footnotetext{
1 Atribuição CC BY: Este é um artigo de acesso aberto e distribuído sob os Termos da Creative Commons Attribution License. A licença permite o uso, a distribuição e a reprodução irrestrita, em qualquer meio, desde que creditado as fontes originais.

2 Doutor em Letras - Literaturas de Língua Portuguesa. Universidade Federal de Minas Gerais - UFMG. E-mail: marcalwellington@yahoo.com.br.
} 
The present work approaches the way Odete Semedo, in her literary text and specifically in the short story Naquela Noite, uses strategies which can be considered as a possible symbolization of "sites of memory". Such strategies reinforce resistance mechanisms and indicate ways of survival to go through difficult periods in the troubled space of Guinea-Bissau. The discussion that is now underway intends to endorse part of the thought of Amílcar Cabral, the most expressive revolutionary leader on the Guinean ground, in which the greater meaning of his people's struggle for independence is clarified.

Cabral's lucid perception seems to be the same that can be seen in the work carried out by Semedo when he enacts, in his literary project, possibilities for the Guinean people to assume, even with great difficulties, the direction of their destiny. The strategies assumed by the writer configure a literary project of a politicized nature.

Semedo's artful writing is processed by the assumption of elements of modernity that blend with features of a voice and gestures universe, with the configurations of collective memory that survive, in their narratives, written in letters and published in the form of a book.

The various dimensions in which memory becomes motivated for Semedo's enunciative fabric allow a rethinking of this author's forceful stance to excavate the terrain of oralities and reinsert them in the written text. This is the path chosen by the writer to keep important traits from her culture from disappearing. Wouldn't such ingenuity allow us to consider, in Semedo's literary creation, notably in her short stories, supports of "sites of memory", as conceived by Pierre Nora?

In order to try to answer this question, it is pertinent to consider the oscillations when the theorist talks about "saving and losing" "guardar $e$ perder' (NORA, 1993, p. 7, my trans.), so typical of the present time. Therefore, it is appropriate to use the short story Naquela noite, from the book Djênia, by Semedo.

The expression "sites of memory" was originally used by Pierre Nora to define the meanings of certain spaces and / or constructions that, according to the historian, indicate, by their very
Palavras-chaves: Descolonização. Memória. Literatura guineense - crítica e interpretação. existence, that there is no more spontaneous memory.

This work already suggests the reasonable functioning of memory strands in literary texts designed by their creators as spaces for the resumption of the past and of features of tradition. In some way, such literary texts indicate a breaking with the deliberate burial of elements proper to the constitution of social nuclei silenced by the "interior decolonization" 'descolonização interior' (NORA, 1993, p. 7, my trans.) movement, as emphasized by Nora.

Literary texts do not claim to replicate the past, because, obviously, this would not be possible. Nor does literary art claim to be a mirror of the world. However, Fonseca writes that the "literature that is attentive to the vestiges and manifestations of oral cultures takes the gesture that legitimizes 'sites of memory', but it can also populate them with the affections promoted by reading" 'a literatura que se faz atenta aos vestígios e manifestações de culturas orais assume o gesto que legitima os "lugares de memória", mas pode também, povoá-los com os afetos que a leitura agencia' (FONSECA, 2005 , p. $59 ; 2008$, p. 88 , my trans.).

In this sense, it is pertinent to observe some strategies with which Semedo sets in motion the intention of resuming elements of the Guinean people's traditions, investigating excerpts from the short story Naquela Noite, which allow following the textual mechanisms with which the author revisits the flavor and rhythm of oral productions so present in her culture. For a better fluency of this work, all excerpts and references, from this moment on, will be taken from the edition published in the year 2000, by Guinea-Bissau's INEP. Only the respective page to which the fragments belong will be registered.

The insomnia night, in its apparent simplicity, seems to enunciate a writer's positioning, as it is typical of the Semedian literary creation. It is as if the fact never experienced by that woman, "who had so often heard complaints from colleagues and friends for having insomnia" "que tantas vezes ouvira queixas de colegas e pessoas amigas por terem tido insônia' (p. 106, my trans.), reintegrates her into a social fabric that is annoyed with something around it, such as the pseudoletargy of her own people and 
the difficulty demarcating her space. Nora reflects on the process of independence and decolonization of the so-called peripheral spaces, pointing out that:

\begin{abstract}
.... the independence of the new nations led to the historicity of societies already awakened from their ethnological sleep by colonial violence. And by the same movement of interior decolonization, all ethnic groups, groups, families, with a strong memory and a weak historical background.

a independência das novas nações conduziu para a historicidade as sociedades já despertadas de seu sono etnológico pela violentação colonial. E pelo mesmo movimento de descolonização interior, todas as etnias, grupos, famílias, com forte bagagem de memória e fraca bagagem histórica. (NORA, 1993, p. 8, my trans.)
\end{abstract}

In the story, one could then consider the "day with tremendous indisposition" 'o dia com uma tremenda indisposição' (p. 106, my trans.) faced by the narrator as the reason for thinking about the process of interior decolonization mentioned by Nora. It is not by chance that the character, in a view of herself, exposes "the fear of people thinking that.... was going crazy" 'o medo de as pessoas pensarem que [...] estava a ficar maluca' (p. 106, my trans.). She that has always "listened to [insomnia] complaints with a certain irony....because she considered it impossible for a person not to sleep at night, especially when lying in a soft bed with a good blanket and a cozy panu di penti" 'ouvia as queixas [de insônia] com uma certa ironia [...] pois considerava impossível uma pessoa não dormir à noite, sobretudo estando deitada numa cama macia com boa coberta e um pano de pente aconchegante' (p. 106, my trans.).

It is precisely at this point that the keen politicized feature of Semedo's literature manifests itself, prompting regards to her work, specifically in what concerns Nora's statements about "sites of memory", the "passada". According to Semedo, "passada" is a retelling; a narration of facts done with emphasis, gossiping 'reconto; narração de acontecimentos feita com ênfase, fofoca' (p. 138, my trans.). It is not an accident that the story emphasizes, on the enunciative level, the relationship between the constituent signifiers of the expressions "soft bed", "good blanket" and "cozy panu di penti" (p. 106, my trans.) to highlight a plausible path for the survival of the tradition in a conversation with elements of modernity. The tensions resulting from this mixture are figuratively expressed by details referring to lack of sleep and other disorders that affect the character. From the simplicity of the plot, only seemingly trivial indications emerge with which makes present the message sent by the writer's hand, the waking up to a new life.

Even though she is unwell and without alternatives, the psychology student sees that a good night's sleep would solve the problem. Yet:

In bed, that feeling of sadness and nostalgia came back to me, it seemed that I had an inexplicable pain in my chest; my heart felt tight and I couldn't sleep. I went around and around in bed but... Nothing! It gave me the feeling that the bed was hot and with the heat that was felt, it was at least an unbearable night; or was it just me who felt that sensation?

Já na cama, voltou-me aquela sensação de tristeza e nostalgia, parecia que tinha uma dor inexplicável no peito; senti o coração apertado e não consegui dormir. Dei voltas e mais voltas na cama, mas... nada! Deu-me a sensação de que a cama estava quente $e$ com o calor que se fazia sentir, era no mínimo uma noite insuportável; ou será que só eu é que sentia aquela sensação? (p. 106, my trans.)

The intimate tone presented in this first part of the "passada", as it has been discussed, could be understood as a synthesis of what a lot of people in the society of which that woman is part feel and experience. People who might also have been "in trouble but who didn't go to the doctor for that reason" "com problemas mas que nem por isso iam ao medico' (p. 106, my trans.) and who, without knowing for sure the reasons for what they felt, went through unbearable nights in the hope of "sleeping as usual and the next day would be another day" 'dormir como de costume e o dia seguinte seria um outro dia" (p. 106, my trans.).

Prudence suggests taking into account the context of the production of Semedo's writing. The Guinean political scene is troubled in such a way that, not on purpose, it would counteract a writing that dialogues and questions this reality. A writing that turns over the alleged official history to build, with recurrence to memory, another possibility of being in the world, showing the pains of this society, and, mainly, the pains of those who had their 
existence thrown to the margins, to the periphery. Doesn't it seem to be the place of belonging of the woman with insomnia from the short story Naquela Noite? Who knows, despite her acknowledging that modernity, in which her life is inserted, has removed her from the living memory of her culture and, perhaps because of this, the badly slept and unhappy night is the trigger for the identity crisis that makes her "wanting to cry" 'querer chorar', wanting to "even give a huge cry" 'mesmo dar um grito enorme' (p. 106, my trans.).

This woman's desolation seems to echo the sentiment of Guineans abused by colonization. And if the "passada" is projected for the current times of that country, in which the dreams that moved the struggles for independence almost completely shattered, more voices would be mixed with the woman's confusion who "did not understand why people fall in love, and why this feeling can suddenly fade or become very complicated" 'não entendia por que é que as pessoas se apaixonam, e por que é que este sentimento pode desvanecer-se de repente ou tornar-se muito complicado' (p. 107, my trans.).

Therefore, it is pertinent to perceive these signs as manifestations of the awakening from ethnological sleep, to use Nora's terms. This awakening that seems to lead her to "doubts that that night became guillotines, not for a sudden death, but to torture [her] slowly" 'dúvidas que nessa noite se tornaram guilhotinas, não para uma morte súbita, mas para [a] torturar lentamente' (p. 107, my trans.). The shock that makes her think of "sad things" 'coisas tristes' (p. 107, my trans.) would be spread, in the character's own perception, towards the community:

My God, what things did I think about that night? I thought of many more things... I had the impression of having been watching a film in which I and the people with whom I live and relate, in my daily life, were the main actors; but there was a lot of sadness in the air, a lot of uncertainty and a lot of disappointment.

Meu Deus, em que coisas fui pensar naquela noite? Pensei em muitas coisas mais... tive a impressão de ter estado a ver um filme em que eu e as pessoas com as quais convivo $e$ me relaciono, no meu dia-a-dia, éramos os atores principais; mas pairava muita tristeza no ar, muita incerteza e muita desilusão'. (p. 107, my trans.)
The dark, disenchanted, murky atmosphere ackowledged by the woman cries out for refuge, for help. The clash in which those who are going through the "interior decolonization movement" "movimento de descolonização interior', according to Nora, (1993, p. 8, my trans.) will lead to the use of writing as a saving mechanism. This would be a movement of interior decolonization that would eventually bring pieces of memories to the surface of the text. For Nora, "this pulling out of memory under the conquering and eradicating impulse of history has a kind of revelation effect: the rupture of a very old identity link, at the end of what we experienced as evidence: the adequacy of history and memory" 'esse arrancar da memória sob o impulso conquistador e erradicador da história tem como que um efeito de revelação: a ruptura de um elo de identidade muito antigo, no fim daquilo que vivíamos como uma evidência: a adequação da história e da memória' (NORA, 1993, p. 8, my trans.).

The balance of the decolonization process needs to be housed in some device. In the meantime, Nora would draw attention to the places that society created to allocate remnants of memory erased by history. These would be places to anchor memory, due to the fact that she no longer habitually and traditionally inhabits the spontaneity of relationships. According to Nora, "if we still inhabited our memory, we would not need to consecrate places to it. There would be no places because there would be no memory carried by history" 'se habitássemos ainda nossa memória não teríamos necessidade de lhe consagrar lugares. Não haveria lugares porque não haveria memória transportada pela história' (NORA, 1993, p. 8, my trans.).

In the "passada", which allows the character to "hide those sad and monotonous thoughts" 'dissimular aqueles pensamentos tristes $e$ monótonos' (p. 107, my trans.), is the recourse to memory, which, in Nora's terms, lends itself to "sudden revitalizations" 'repentinas revitalizações' (p. 107, my trans.). It is worth presenting an excerpt in which the main character of the story finds an alternative to the sensation experienced on this night of "sadness and desolation" 'tristeza $e$ desolação' (p. 107, my trans.):

The sadness was great and the lack of sleep was even greater; so I got up and went into the living room, lit the lamp and looked for a pen and one of my daily notebooks. I sat down. What will I study? No, I will not study, 
I will write something... But what? I didn't know. Then I started flip through the notebook, rereading some notes. After reading a few pages, I started to feel heavy eyelids; it could not be drowsiness, because I was not sleepy, and I continued ...?

A tristeza era muita e a falta de sono maior ainda; então, levantei-me e fui até a sala, acendi o candeeiro e procurei uma caneta e um dos meus cadernos diários. Sentei-me. $O$ que será que vou estudar? Não, não vou estudar, vou escrever qualquer coisa... Mas o quê? Não soube. Aí comecei a esfolhar o caderno, a reler alguns apontamentos. Após ter lido algumas páginas, comecei a sentir as pálpebras pesadas; sono não podia ser, porque estava sem sono, e continuei...? ( $p$. 107-108, my trans.)

The enunciation seems to assert the situation experienced by that woman and, also, by the people around her, who belong to societies that were removed by the course of a history that was imposed on them; removed from the living memory that constituted them.

Accepting Nora's postulate helps to understand, in Semedo's "passada", the connection of what could be called the second part of the narrative, or, perhaps, of a narrative embedded in the main one, whose marking would be on the "heavy eyelids," 'pálpebras pesadas' (p. 107, my trans.) reinforced in the ellipsis and in the question mark that close that paragraph. These signs lead one to believe that the woman falls asleep, or, at least, dozes off and the enunciation enters the dream universe, making the reader participate in what goes on in the character's mind at those moments. The reader knows that, when browsing through her diary, she finds a note from Rosa, an Angolan friend of her sister. She takes it upon herself to answer her, in return to this foreigner who had liked the country so much, according to which, this was "a beautiful, small and clean land" 'uma terra linda, pequena $e$ limpa' (p. 108, my trans.).

Could we think about the note as a metadevice used to house remnants of memories? Or, still, as the only possible way to stop the crazy course of history and to store pieces of things that no longer exist? If the answer is positive, reading the note written to the Angolan Rosa, in the dream, materializes the narrative resource used by Semedo, since it will be in the note that aspects of the manipulation carried out by dominant social groups of that society will be highlighted.
Undoubtedly, social groups remain in constant conflict to arbitrate what will be elected to be highlighted at a given historical moment. The sudden revitalizations, as Nora ponders, are full of intention. In this game, the grouping of greater power will prevail. The other social parcels, regardless of their size, will have to conform to the gesture of perennial manipulation. However, the groups that still live in the heat of living memory end up finding artifices to emerge from long latencies and, in this way, show the contiguity between past and present. Memory, says Nora, is nourished by "vague, telescopic, global or floating memories, private or symbolic, sensitive to all transfers, scenes, censorship or projections" lembranças vagas, telescópicas, globais ou flutuantes, particulares ou simbólicas, sensivel a todas as transferências, cenas, censura ou projeções' (NORA, 1993, p. 9, my trans.).

It is pertinent to point out that Rosa, the Angolan, is someone "who came on an excursion" 'que viera numa excursão' (p. 108, my trans.), who had been in a "country that she always [wanted] to know" 'país que sempre [quisera] conhecer' (p. 109, my trans.), although the visit lasted only a week. Her assessment that it was "a beautiful, small and clean land", does not seem to agree with the hostess's feeling, since she "would very much like [Rosa's group] to stay longer, so that we can exchange more experiences and get to know each other better" 'gostaria muito que [o grupo de Rosa] ficasse por mais tempo, para podermos trocar mais experiências e conhecermo-nos melhor' (p. 109, my trans.; emphasis added). Certainly, there is something that escaped the visitor's eye and that deserves to be better shared, but that would be for another opportunity. Writing that is not done for free has, as one of its main characteristics, the ability to play the game between what to remember and what to forget and when to do it.

In the story, an apparent filigree, full of meaning, can be seen in the final section of the note in which different ways of contemplating the things of nature are known. It is noteworthy that there is a communion of the rare habit of enjoying the sunset. This slowdown, at least at that specific moment, unites people from countries far away as it works to resume memories. This can be seen in the excerpt: "I will make sure to send you a postcard with the image of the setting sun in Saint Thomas. I know you like it, because I made you a surprise, in the afternoon of the day we went to the Bijagos Islands, to enjoy the sunset. I didn't call you, or make a noise, so as not to break the spell" 'Farei questão de te enviar um postal 
com a imagem do sol poente em S. Tomé. Sei que gostas, pois surpreendi-te, na tarde do dia em que fomos às Ilhas Bijagós, a apreciar o sol poente. Não te chamei, nem fiz barulho, para não quebrar o encanto' (p. 110, my trans.). Enjoying the sunset, in a way, seems to be taking up time and habits from the past, which, in the story, are painted in expressions like "panu di penti" and in reference to the sunset. Such resources can be thought of as indicators of a spatialization of memory that, according to Nora, "takes root in the concrete, in the space, in the gesture, in the image, in the object" 'se enraíza no concreto, no espaço, no gesto, na imagem, no objeto' (NORA, 1993, p. 9, my trans.).

The woman's worries seem to be much more attenuated when her moment of reverie is accompanied by the reader. However, when she wakes up, she is swallowed up again by the marked life, by "sadness and desolation" 'tristeza e desolação' (p. 107, my trans.). Here is the scene:

I was startled by the noise of the door. After all, I had managed to overcome insomnia and fell asleep, with my open notebook as a pillow. I opened the notebook looking for the letter I had written and... nothing! There was no letter. After all, it had only been a dream. And I had the feeling that it was a very beautiful letter. But I don't even remember the contents of the small note. And Rose of Angola? Was it all a dream? What a shame! I even imagined her beautiful, passionate about life, always in a good mood. Medium height, strong and long hair, elegant...! How good it would be, if it were true!

Sobressaltei-me com o barulho da porta. Afinal tinha conseguido vencer a insônia $e$ adormecido, com o caderno aberto servindo-me de travesseiro. Abri o caderno à procura da carta que tinha escrito e... nada! Não havia carta nenhuma. Afinal tinha sido apenas um sonho. E ficou-me a sensação de que era uma carta bem bonita. Só que já não me lembro nem do conteúdo do bilhetinho. E a Rosa de Angola? Será que foi tudo um sonho? Que pena! Até já a imaginava bonita, apaixonada pela vida, sempre de bom humor. Altura mediana, cabelos fortes e longos, elegante...! Que bom seria, se fosse verdade! (p. 110, my trans.)

Staging the memory in the way Semedo did in Naquela Noite ends up becoming a strategy to bring to the same space elements of different temporalities and to accentuate traces of traditions that are swallowed by the accelerated time. In a way, the tale articulates elements of what Nora considers as parts of the process of interior decolonization and Achugar perceives it as fear of memory loss caused by the "ghost of a collective Alzheimer" 'fantasma de um Alzheimer coletivo' (2006, p. 168, my trans.).

In the case of people in the process of decolonization, the most certain thing is that those who choose to face the imposition of forgetfulness walk in opposition to the sovereign power, because, as Todorov emphasizes: "every act of reminiscence, even the most humble, could be assimilated to antitotalitarian resistance:....the reconstruction of the past was already perceived as an act opposed to power" 'Todo ato de reminiscência, mesmo o mais humilde, pôde ser assimilado à resistência antitotalitária: [...] a reconstituição do passado já era percebida como ato de oposição ao poder' (2002, p 140 , my trans.).

It is Todorov who warns to the fact that "the status of memory in democratic societies does not seem definitively guaranteed" 'estatuto da memória nas sociedades democráticas não parece definitivamente garantido' (2002, p. 141, my trans.). Perhaps that is why it is possible to understand, in Semedo's tale, the awakening of the woman and her desire that her wanderings in the dream could, in fact, be a reality to realize possibilities of living together and restoring habits such as writing letters, sending postcards and enjoying the charm of the setting sun.

Semedo's literary text materializes a strategic action, poetically defined by Nora "the deciphering of what we are in the light of what we are no longer" 'o deciframento do que somos à luz do que não somos mais' (NORA, 1993, p. 20, my trans.), from the voice of anyone, from any human face.

The decision to turn to the analysis of part of Semedo's narratives was caused, in particular, by reflections on the concepts of memory and "places of memory". These concepts allowed me to scan the configurations of the physical places that hold memory and their meanings in the fictional space. It is also possible to highlight the way in which the writer operates to manage the dialogues between literary writing and orality, as well as its relationship with data from Guinea's historical past.

This work, fueled by these reflections, can verticalize the discussion by focusing the symbolization of the "places of memory" in Semedo's text, emphasizing, in the enunciation of it, its performativity as a marker of resistance and an 
input for survival to overcome the hardness of current times of Guinea-Bissau. In Naquela Noite, Semedo's dexterity is proven by her skill of handling the concomitance of divergent times and spaces, as

\section{REFERENCES}

ACHUGAR, H. O lugar da memória: a propósito de monumentos (motivos e parênteses). In:

Planetas sem boca: escritos efêmeros sobre arte, cultura e literatura. Tradução de Lyslei Nascimento. Belo Horizonte: UFMG, 2006. p. 167-184.

CABRAL, A. A arma da teoria: unidade e luta. Praia: Fundação Amílcar Cabral, 2013. 299 p. (Obras escolhidas de Amílcar Cabral, 1).

A prática revolucionária: unidade e luta. Praia: Fundação Amílcar Cabral, 2013. 266 p. (Obras escolhidas de Amílcar Cabral, 2).

Colonização e religião: da primeira

evangelização à colonização dos povos da Guiné.

Soronda - Revista de Estudos Guineenses, n. 5, jan. 1988.

FONSECA, M.N.S. Percursos da memória em textos das literaturas africanas de língua portuguesa. Gragoatá:

Revista do Instituto de Letras, Niterói, n. 19, p. 45-63, 2. sem. 2005.

Percursos da memória em textos das

literaturas africanas de língua portuguesa. In: Literaturas africanas de língua portuguesa: percursos da memória e outros trânsitos. Belo Horizonte: Veredas e Cenários, 2008. p. 73-91.

NORA, P. Entre memória e história: a problemática dos lugares. Tradução de Yara Aun Khoury. Projeto História, São Paulo, n. 10, p. 7-28 dez. 1993.

. Les lieux de mémoire. Paris: Gallimard, 1985. well as the remains of traditions threatened with extinction due to the acceleration of history.
SEMEDO, M.O. da C. Em que língua escrever. In: Entre o ser e o amar. Bissau: INEP, 1996. p. 11-13. (Kebur, 3).

Djênia: histórias e passadas que ouvi contar. Bissau: INEP, 2000. 143 p. v. 2.

. [Mais] conversa com... Odete Semedo.

Boletim + Escola, n. 11, p. 6. maio. 2009.

As mandjuandadi - cantigas de mulher na

Guiné-Bissau: da tradição oral à literatura. Orientadora: Maria Nazareth Soares Fonseca. 2010. 415 f. Tese (Doutorado em Letras) - Pontifícia Universidade Católica de Minas Gerais, Programa de Pós-graduação em Letras, Belo Horizonte, 2010.

Entrevista, em 10 de março de 2010, concedida à Maria Coelho e Vera Sales. In: FERREIRA, V.L. da S.S. Lembrar e carpir: estratégias de construção de poemas escritos por mulheres nas literaturas africanas de língua portuguesa. Orientadora: Maria Nazareth Soares Fonseca. 2011. 215 f. Tese (Doutorado em Letras) - Pontifícia Universidade Católica de Minas Gerais, Belo Horizonte, 2011.

Guiné Bissau: histórias, culturas, sociedades e literatura. Belo Horizonte: Nandyala, 2011. 132 p.

No fundo do canto. Belo Horizonte: Nandyala, 2007. 198 p.

Sonéá: histórias e passadas que ouvi contar. Bissau: INEP, 2000. 153 p. v. 1.

TODOROV, T. A conservação do passado. In: Memória do mal tentação do bem: reflexões sobre o século XX. Tradução de Joana Angélica D'Avila. São Paulo: Arx, 2002. p. 133-171.

\section{How to cite (ABNT)}

CARVALHO, Wellington Marçal de. The symbolization of sites of memory in Naquela Noite, a short story by the guinean writer Odete Semedo. JOSSHE: Journal of Social Sciences, Humanities and Research in Education. v. 3, n. 1, p. 1-7, Jan./June, 2020. DOI http://dx.doi.org/10.46866/josshe.2020.v3.n1.70. 